\title{
ASSAY AND GRAPHITE FURNACE- ATOMIC ABSORBANCE SPECTROMETRY ACCURACY FOR PALLADIUM CONTENT ANALYSIS
}

\author{
Ronaldo Irzon', Kurnia' \\ ${ }^{1}$ Center for Geological Survey, Bandung \\ The Ministry of Energy and Mineral Resources \\ e-mail : ronaldoirzon18@gmail.com
}

\begin{abstract}
Palladium is a member of the expensive Platinum Group Metals as it is indispensable for various applications of modern technology. Due to the very small number of these elements in nature, high-sensitivity analytical methods and devices are required for accurate PGM measurement. The current study aims to determine the accuracy level of the Graphite Furnace-Atomic Absorbance Spectrometry device for palladium analysis after pre-concentration through the assaying process. The studied samples were two in-house standard reference samples with stream sediment and ultramafic rock matrices. Due to the lack of certified reference material containing certain palladium compositions, the degree of accuracy was tested by the spiking method. The detection limit for $\mathrm{Pd}$ in this study was $11.79 \mathrm{ppb}$. $\mathrm{Pd}$ content in the stream sediment (17 ppb) is much lower than of the ultramafic sample (290 ppb), implying PGM association to ultramafic rock naturally. Almost all measurements have good accuracy according to spike recovery between $80-120 \%$. Inaccurate addition process and inappropriate calibration range most probably lead to inaccuracy.
\end{abstract}

Keywords: palladium; GF-AAS; assay; spiking

Received: 2020-12-31; Revised: 2021-03-22; Accepted: 2021-03-23

\section{INTRODUCTION}

Accuracy is one component of the acceptance level of a measurement result as well as precision. Standard reference material is necessary for determining the degree of analytical accuracy, while repeated measurements are required for the precision test [1][2][3][4]. Certified Reference Material (CRM) is known as the most trusted reference material for accuracy verification. It has been tested in various certified laboratories, and the manufacturing process is supervised by an international accreditation body [5][6][7]. Various studies were carried out for CRM replacement and assistance due to its high price, small number, and limited matrix. Various laboratories generated their own in-house reference materials from their most analysed matrix [6][8][9]. The spiking method, which is attained by adding a certain amount of material, is the most adapted solution to overcome the absence of standard materials [3][10][11][12]. Spiking accuracy simply is defined on the spike recovery as a comparison of the analyte content in the sample before and after the standard material addition.

Palladium $(\mathrm{Pd})$ is classified in Platinum Group Metals (PGM) along with platinum (Pt), rhodium (Rh), osmium (Os), ruthenium $(R u)$, and Iridium (Ir). This group of elements is rare in nature so that it is strategic and expensive. In the earth's crust, the PGM amount is even less than the lanthanide group element, which is predicted as modern technology material. PGM is crucial in the automotive, catalyst, jewellery, electronics, and electric car industries [13][14][15]. Various usefulness of the PGM group is summarised in Table 1. Naturally, PGM is associated with base metals and is concentrated in ultramafic-mafic sulfide saturated igneous rocks with abundant iron (Fe)Copper (Cu) concentrations [2][3][16]. Therefore, PGM is widely exploited in South Africa, Canada, Russia, and Zimbabwe [14][17]. In Indonesia, PGM studies were mostly 
conducted in South Kalimantan, South Sulawesi, and Southeast Sulawesi because of the wide ultramafic-mafic rocks distribution in these regions [18][19].

The necessity for a high sensitivity analytical device is a consequence of measuring PGM because of the low abundance. Hence, Inductively Coupled Plasma-Mass Spectrometry (ICP-MS) and Instrumental Neutron Activation Analysis (INAA) were widely applied in the PGM studies [2][3][21][22][23]. Other analytical instruments are adoptable but with certain engineerings such as extraction, leaching, electrowinning, assaying, and coprecipitation [14][15][24]. A combination of leaching, assaying, and ICP-MS devices were utilised in preventing analytical inaccuracies [25]. However, other analytical devices are adaptable for PGM analysis after various pre-concentration or optimisation processes. Preparation process complexity and the need for a high sensitivity analytical instrument are probably the obstacles to PGM studies in Indonesia.
North Konawe is situated in the Southeast Sulawesi Province with a wide distribution of ultramafic rocks. Olivine, pyroxene and hornblende are the main minerals in ultramafic rocks there [19]. In addition, serpentine, ilmenite, and kaolinite are accessory minerals sometimes found in altered ultramafic rocks. Although ultramafic rock exploration in North Konawe is mostly associated with nickel [19], the PGM content is worth investigating because of this metal group correlation towards the ultramafic and mafic rocks.

This study aims to determine the degree of accuracy of the Graphite Furnace-Atomic Absorbance Spectrometry (GF-AAS) method for palladium analysis after pre-concentration through the assaying process. An ultramafic rock from North Konawe and a stream sediment sample of Citarum River were selected for this study. This investigation results would support the development of palladium-associated industry in Indonesia.

Table 1. Platinum Group Metals sub-divisions and their industrial application [13][20].

\begin{tabular}{|c|c|c|}
\hline $\begin{array}{l}\text { PGM sub- } \\
\text { group }\end{array}$ & Element & Industrial Utilities \\
\hline 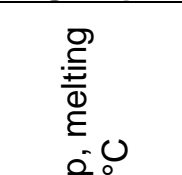 & Os & $\begin{array}{l}\text { Process catalyst for syn-dihydroxylation, } \\
\text { electrical contacts, light filaments, staining } \\
\text { agent in electron microscopy, jewellery, } \\
\text { fountain pen points. }\end{array}$ \\
\hline 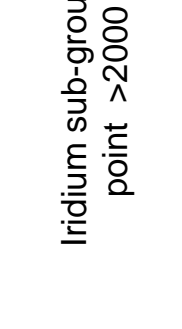 & $\mathrm{Ru}$ & $\begin{array}{l}\text { Coating of dimensionally stable anodes } \\
\text { (DSA), Process catalyst (for hydrogenation, } \\
\text { acetic acid synthesis, and hydroformylation), } \\
\text { jewellery fabrication, catheters. } \\
\text { chlor-alkali industry, ammonia synthesis, } \\
\text { hydrocarbon synthesis, hydroformylation, } \\
\text { computer hard drive, anti-corrosion piping, } \\
\text { dentistry. }\end{array}$ \\
\hline 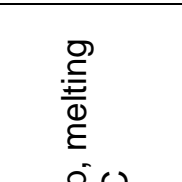 & $\mathrm{Rh}$ & $\begin{array}{l}\text { The alloying agent with Pt in thermocouples, } \\
\text { sliding and pressure contacts, jet engine glow } \\
\text { plugs, electroplating, ammonia catalytic } \\
\text { oxidation. }\end{array}$ \\
\hline 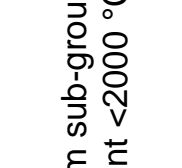 & $\mathrm{Pd}$ & $\begin{array}{l}\text { Multilayer ceramic capacitors (MLCC), hybrid } \\
\text { integrated circuits, plating connectors, lead- } \\
\text { frames, oxygen sensors, petroleum refinery, } \\
\text { exchange-traded funds (as coins). }\end{array}$ \\
\hline 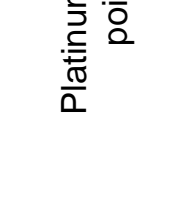 & $\mathrm{Pt}$ & $\begin{array}{l}\text { Jewellery fabrication, dental alloys, } \\
\text { biomedical devices, anticancer drugs, } \\
\text { reforming and isomerisation in petroleum } \\
\text { refinery, optical glass, thermocouples, contact } \\
\text { materials, varistors, and bond wires. }\end{array}$ \\
\hline
\end{tabular}




\section{MATERIALS AND METHODS}

The two in-house reference materials for which $\mathrm{Pd}$ composition was measured in this study are called Citarum 3 and Serpentine. Citarum 3 is stream sediment of the Citarum River from the Bandung Regency area. The rock types traversed by the Citarum River are majorly andesitic to dacitic tuff [26]. Conventional gold mining was conducted in several places along with the river flow. PGM is sometimes correlated with gold [19]. Therefore, Citarum River flow sediments might also contain PGM. The Serpentine was attained from ultramafic rock domains in North Konawe Regency. Those samples were deemed suitable as studied materials due to their strong association of ultramafic rock to PGM.

Atomic Absorption Spectrometry (AAS) instrument works based on the absorption of radiation absorbance by free atoms of an element at a certain frequency and wavelength. This device is commonly used for base metals and precious metals studies, such as $\mathrm{Ca}, \mathrm{Pb}$, $\mathrm{Cu}, \mathrm{Cr}, \mathrm{Mn}, \mathrm{Ag}$, and $\mathrm{Au}$ [27][28][29]. Basically, atomisation in the AAS is carried out using two options, namely flame atomisation and graphite furnace atomisation. The first option uses a flame burner, while the other one adopts a graphite cylinder connected to electrodes at both ends.

Flame atomisation is commonly applied to analyse high concentration metals at a low cost due to the low-temperature requirement of $<3,000{ }^{\circ} \mathrm{C}$ and a short residence time [30]. However, this option is not sensitive enough for trace elements or volatiles measurements.
Although strong electric power is required in the graphite furnace atomisation process, this alternative is preferred for PGM analysis [31] that the option applied in this study.

The samples were crushed and ground in gaining particle size of -200 mesh to accelerate the preparation process. A standard solution containing 1,000 ppm Pd (produced by Spex CertiPrep, Germany) was diluted stratified to obtain a calibration curve and to calculate the detection limit. A fire-assaying scheme that separates metals and impurities based on their melting point [3][32] was carried out to support the analytical device sensitivity. Special protective apparel during the assaying scheme is useful to protect the operator from the furnace's high combustion temperature Figure 1a. The fire-assaying process consists of three stages: flux mixing, fusion reaction, and coupling [3][19]. The selected sample was put together with the flux components $\left(60 \mathrm{~g}\right.$ of $\mathrm{Na}_{2} \mathrm{CO}_{3}, 40 \mathrm{~g}$ of $\mathrm{PbO}, 20 \mathrm{~g}$ of $\mathrm{SiO}_{2}, 25 \mathrm{~g}$ of $\mathrm{Na}_{2} \mathrm{~B}_{4} \mathrm{O}_{7}, 10 \mathrm{~g}$ of $\mathrm{CaF}_{2}$, and $5 \mathrm{~g}$ of flour) in polyethene plastic. For fusion reaction, the furnace was set at $1100^{\circ} \mathrm{C}$ for one hour while the coupling was carried out at $850^{\circ} \mathrm{C}$ for 45 minutes as described in the previous study [3]. The coupling plates of this study are shown in Figure 1b. Prill (Au + PGM) resulted from the assaying process then was separated from the lead button as a compound of impurities before preparation and measurement using the GF-AAS. Entire preconcentration, preparation, and analysis using GF-AAS steps were worked at the Laboratory of Center for Geological Survey, Bandung. 

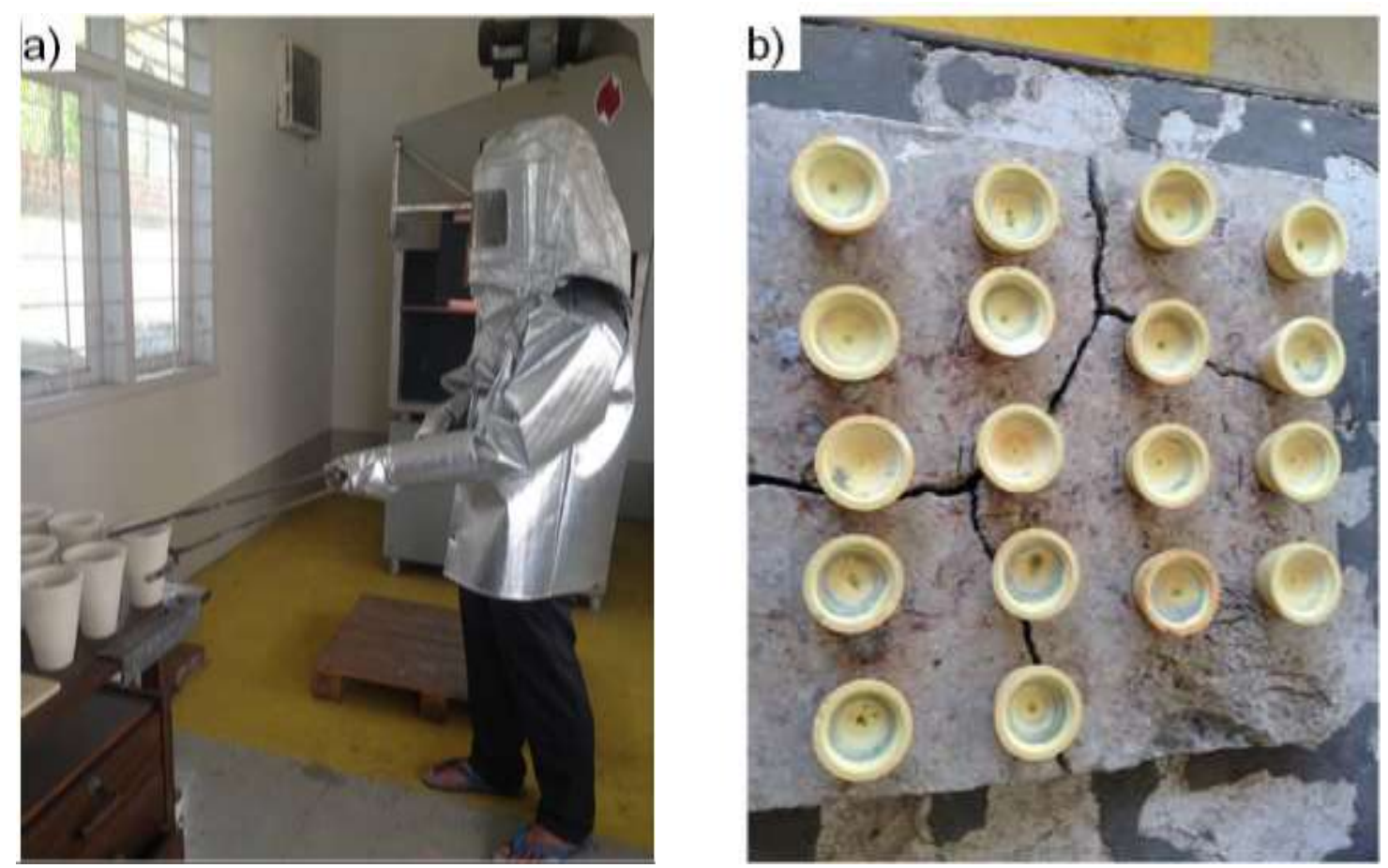

Figure 1. Supporting tools of this study: a) Unique apparel to protect the operator from working in high temperature; b) coupling plates utilised at the end of the fire-assaying process.

The spiking technique was adapted because of no CRM containing guaranteed PGM composition available at the Laboratory of Center for Geological Survey. The accuracy of a spiking method is represented on the spike recovery value $\left(S_{R}\right)$, which is calculated according to Equation 1 below:

$\mathrm{S}_{\mathrm{R}} \%=\frac{\left(\mathrm{C}_{\text {spike }}-\mathrm{C}_{\text {smp }}\right)}{\mathrm{C}_{\text {lar }}} \times 100 \%$

$C_{\text {spike }}, C_{s m p}, C_{\text {lar }}$ is the concentrations after spiking, before spiking, and spike solution, respectively. Standard solutions, which contain 2,500 ppb, 5,000 ppb, and 7,500 ppb of Pd were added to the sample to gain $10 \mathrm{ml}$ final solutions.

\section{RESULTS AND DISCUSSION}

\section{A. Limit of Detection}

Four levels of $\mathrm{Pd}$-containing calibration solutions (blank, $50 \mathrm{ppb}, 100 \mathrm{ppb}$, and $150 \mathrm{ppb}$ ) were measured to draw a calibration curve. The analysis results are then input in linear regression. calculation in Equation 2 to obtain the standard deviation ( $S_{y / x}$ ) applying equation (3) below:

$\mathrm{y}=\mathrm{ax}+\mathrm{b}$

$S_{y / x}=\sqrt{\frac{\sum_{i}^{n}\left(x_{i}-x_{R}\right)^{2}}{n-2}}$

The $y, x, a$, and $b$ parameters in Equation 2 are the measured concentration, the theoretical concentration, the slope of the curve, and the intercept, respectively. Moreover, $x_{i}, x_{R}$, and $\mathrm{n}$ in Equation 3 refer to analytical results, mean concentration, and the number of analyses. Pd limit of detection of this study is three folds of the standard deviation, as illustrated in Equation 4. The curve-based $\mathrm{Pd}$ limit of detection of this study is three folds of the standard deviation, as illustrated in Equation 4. Thus the final LOD was calculated using Equation 5.

$$
\begin{aligned}
y \text { LOD } & =3 S_{y / x} \\
\text { LOD } & =\frac{3 S_{y / x}-b}{a}
\end{aligned}
$$

The calibration curve for the $\mathrm{Pd}$ analysis of this study is shown in Figure 2. 
M.I.P.I. Vol.15, No 2, August 2021 - (121-129)

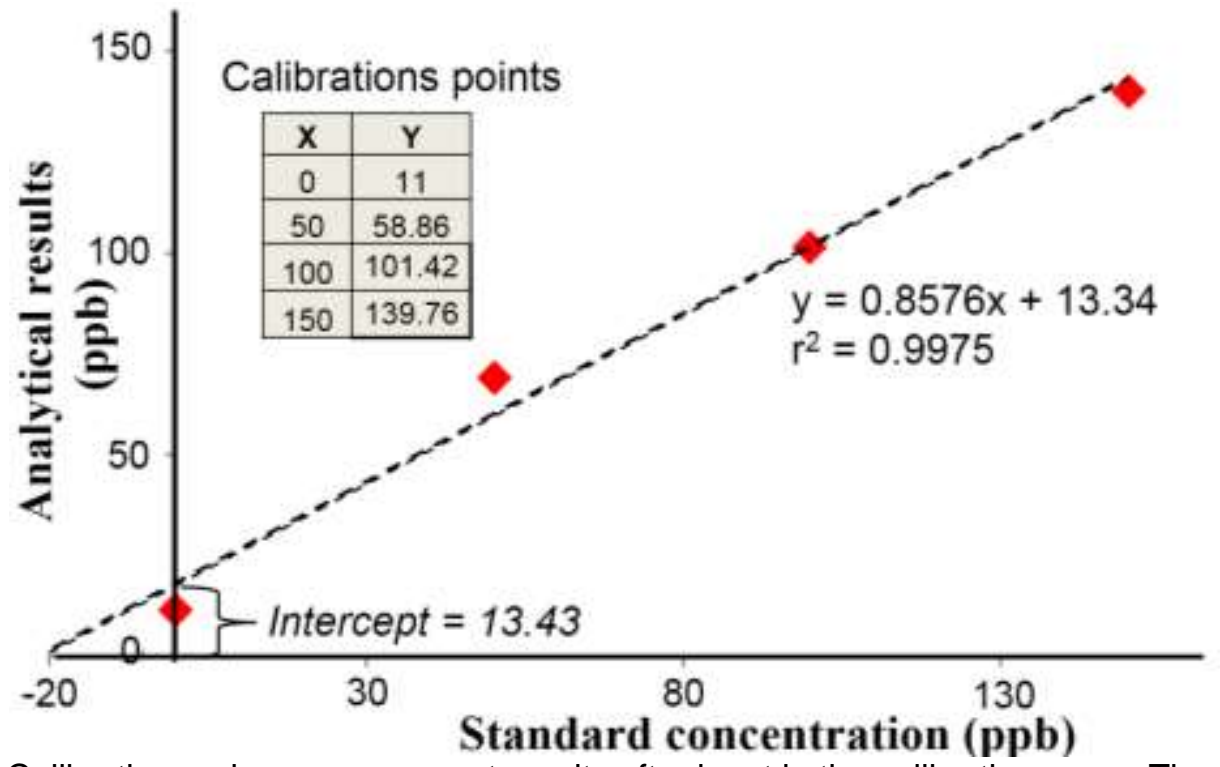

Figure 2. Calibration series measurement results after input in the calibration curve. The intercept is 13.43.

Positive intercept implies that the analytical settings are adequate to detect the lowest analyte content in the solution. On the other hand, a negative intercept suggests that the previous detection limit level is not sufficient to measure analyte abundance [3][19]. So that a negative intercept is considered influential, but the positive one is ignorable. The intercept of the calibration curve is positive Figure 2, so that it was negligible in LOD calculation. Based on Equation 2 - Equation 5, the detection limit for Pd using the GF-AAS method in this study was
$11.79 \mathrm{ppb}$. A very strong positive correlation between the concentration of the prepared standard values theoretically with the analytical results was amplified by the strong calibration coefficient $\left(r^{2}=0.9975\right)$. However, this limit is not as good as a previous study on $\mathrm{Pd}$ measurement using ICP-MS device with LOD $2.29 \mathrm{ppb}$ [3]. This difference proves the higher ICP-MS sensitivity than AAS even though modified with graphite furnace atomisation. Pd measurement results in this study are summarised in Table 2.

Table 2. Pd measurement results of the two in-house reference materials in this study.

\begin{tabular}{lcc}
\hline Sample Codes & $\begin{array}{c}\text { Pd content } \\
\text { (ppb) }\end{array}$ & $\begin{array}{c}\text { Spike } \\
\text { recovery (\%) }\end{array}$ \\
\hline Citarum 3 & 17 & - \\
Serpentine & 290 & - \\
Citarum 3 + Pd 2500 ppb & 2817 & 112 \\
Citarum 3 + Pd 5000 ppb & 5280 & 105 \\
Citarum 3 + Pd 7500 ppb & 9007 & 119 \\
Serpentin + Pd 5000 ppb & 3428 & 125 \\
Serpentin + Pd 7500 ppb & 4717 & 89 \\
Serpentin + Pd 2500 ppb & 7852 & 101 \\
\hline
\end{tabular}




\section{B. Pd content comparison}

Palladium abundance of the Citarum 3 (17 $\mathrm{ppb}$ ) is much lower in comparison to the Serpentine (290 ppb). As a stream-sediment origin sample, the chemical content of Citarum 3 represents the eroded material from the higher ground and draws the material composition of the catchment area. The Citarum River majorly flows through andesitic and dacitic rocks, which are uncommon as PGM-bearing material [26]. Although conventional gold mining was conducted in the vicinity of this river flow, the mineralisation unlikely correlated to PGM. On the other hand, Serpentine was obtained from an ultramafic outcrop that most possibly correlated to $\mathrm{PGM}$ according to the previous reports [2][3][16][19]. Thus the high Pd contents in Serpentine reflect its parent rock composition.

After spiking and calculation using Equation 1 , the accuracy of the test method is in a fairly wide range of $89 \%$ to $125 \%$ Figure 3 . The degree accuracy of the research considered good with a spike recovery of 100 $\pm 20 \%$ as described in the previous studies [3][32][33]. However, the result of Serpentine + $2,500 \mathrm{ppb} P d$ is below the acceptance criteria (spike recovery $\approx 125 \%$ ), which might be because of some inaccuracy during standard Pd addition. PGM analysis was worked at a high sensitivity level as a consequence of its very low concentration in nature. A slight mismatch during spiking should have a significant impact on the final measurement result.

Studied samples were diluted 250 times through pre-concentration and preparation sequences. The lowest concentration for the calibration series is $0 \mathrm{ppb}$ (blank) and the highest at $150 \mathrm{ppb}$, implying that the resulting curve should be most valid for a concentration range of up to $37,500 \mathrm{ppb}$. On the other hand, the upper limit is too far for sample measurement with a maximum content of 7,852 ppb Table 2. Future improvement could be carried out using a lower concentration series for calibration. Then, repeatability and reproducibility works would strengthen this study on the method robustness.

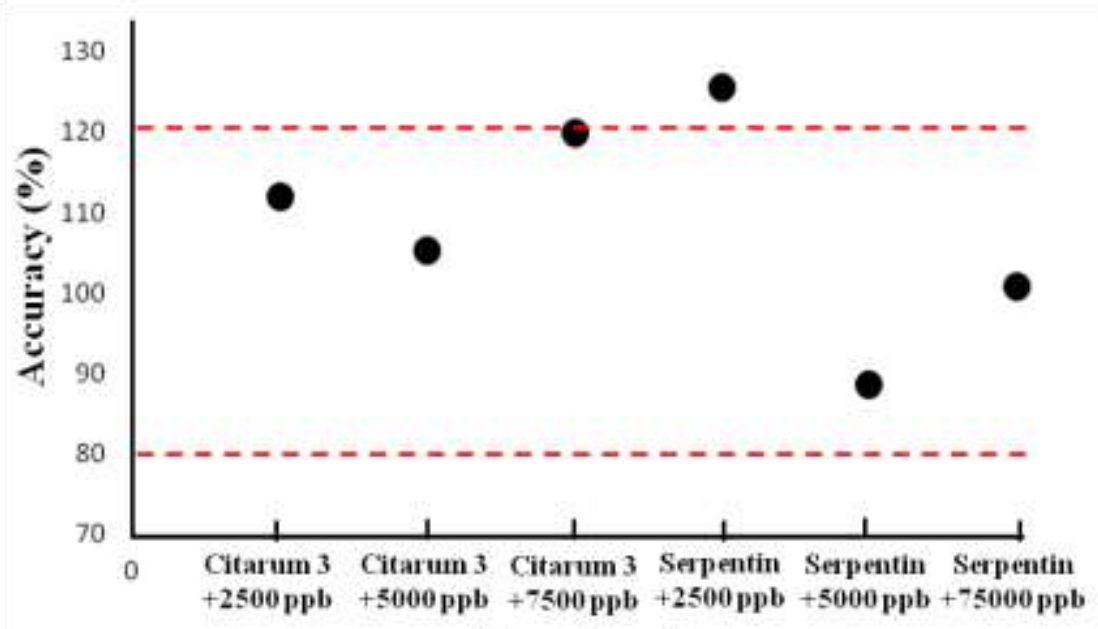

Sample code

Figure 3. The accuracy of the spiking method was determined from the spike recovery in this study. Most of the analysis shows acceptable accuracy with spike recovery between $80 \%$ to $120 \%$.

\section{CONCLUSION}

The palladium concentration of two in-house reference materials was analysed using the GFASS device after pre-concentration by assaying process. The limit of detection was $11.79 \mathrm{ppb}$ that obtained from the measurement on a series of calibration solutions. Pd content in the stream sediment sample from Bandung (17 ppb) was less than the one originated from ultramafic rock in North Konawe (290 ppb). These results reflect PGM natural association with ultramafic to mafic rocks. Almost analysis shows good accuracy with spike recovery between $80-120 \%$. The inaccuracy of one analysis should be caused by errors during $\mathrm{Pd}$ addition and/or inappropriate calibration range. Repeatability and reproducibility tests would improve the proposed method to enhance Pd exploration in Indonesia.

\section{AUTHOR INFORMATION}




\section{Corresponding Authors}

Email: ronaldoirzon18@gmail.com. Phone: +62 88218581366

Email:miharjakurnia@gmail.com.

\section{Author Contributions}

First Author and Second Author have contributed equally to this work.

\section{ACKNOWLEDGMENTS}

The authors would like to thank the Head of the Center for Geological Survey for the publication permission. Fieldworks were fully assisted by Mr. Baharuddin, Mr. Usep, and Mrs. Erna. We also appreciate Mr. Deni's helps with the laboratory works.

\section{REFERENCES}

[1] Fakhreddine, S., Lee, J., Kitanidis, P. K., Fendorf, S., Rolle, M., Imaging geochemical heterogeneities using inverse reactive transport modeling: An example relevant for characterising arsenic mobilisation and distribution, Advances in Water Resources, vol.88, 2016, p.186-197.

[2] Ako, T.A., Vishiti, A., Suh, C.E., Kedia, A.C., Omang, B.O., Geological Models of Platinum Group Elements (PGE) Depletion in Metamorphosed Ultramafic Rocks of the Nyong Series, Southeast Cameroon, International Journal of Mining Science, vol. 3(4), 2017, p.1-12.

[3] Irzon, R., Kurnia, K., Skema Fire Assay dan ICP-MS Pada Pengukuran Kadar Paladium dalam Sampel Batuan, Majalah Ilmiah Pengkajian Industri, vol.13(2), 2019, p.187194.

[4] Irzon, R., Syafri, I., Ghani, A. A., Prabowo, A., Hutabarat, J., Sendjaja, P., Petrography and Geochemistry of the Pinkish Lagoi Granite, Bintan Island: Implication to Magmatic Differentiation, Classification, and Tectonic History, Bulletin of the Geological Society of Malaysia, vol.69, 2020, p.27-37.

[5] Bulska, E., Reference Materials in Chemical Measurements. In Metrology in Chemistry (p. 65-86), 2018, Springer, Cham.

[6] Irzon, R., Pembuatan Material Acuan Internal Berupa Batuan Pada Zona Kaolinisasi dari Kokap Kulon Progo
Menggunakan ICP-MS, Jurnal Standardisasi, vol.19(2), 2018, p.103-112.

[7] Olivares, I.R.B., Souza, G.B., Nogueira, A.R.A., Toledo, G.T.K., Marcki, D.C., Trends in Developments of Certified Reference Materials for Chemical AnalysisFocus on Food, Water, Soil, and Sediment Matrices, TrAC Trends in Analytical Chemistry, vol.100, 2018, p.53-64.

[8] Ardakani, O.H., Sanei, H., Snowdon, L.R., Outridge, P.M., Obermajer, M., Stewart, R., Vandenberg, R., Boyce, K., The Accepted Values for the Internal Geological Survey of Canada (GSC) 9107 Rock-Eval 6® Standard (Upper Cretaceous Second White Speckled Shale, Colorado Group), Western Canada, Geological Survey of Canada, 8043, 2016, 9p.

[9] Rohyami, Y., Yuliani, A.I. and Firdiyanti, H.I., 2018, October. Recrystallisation of sodium chloride as the candidate of inhouse reference material. In AIP Conference Proceedings (Vol. 2026, No. 1, p. 020052). AIP Publishing LLC.

[10] Han, J., Lin, K., Sequeira, C., Borchers, C. $\mathrm{H}$., An isotope-labeled Chemical Derivatization Method for the Quantitation of Short-chain Fatty Acids in Human Feces by Liquid Chromatography-Tandem Mass Spectrometry, Analytica Chimica Acta, vol.854, 2015, p.86-94.

[11] Abou Al Alamein, A.M., Validated Ecofriendly Chromatographic Methods for Simultaneous Determination of Sacubitril and Valsartan in Spiked Human Plasma and in Pharmaceutical Formulation, Journal of Applied Pharmaceutical Science, vol.8(2), 2018, p.011-017.

[12] Idris, A.M., Said, T.O., Brima, E.I., Sahlabji, T., Alghamdi, M.M., El-Zahhar, A.A., Arshad, M., El Nemr, A.A., Assessment of Contents of Selected Heavy Metals in Street Dust from Khamees-Mushait City, Saudi Arabia Using Multivariate Statistical Analysis, GIS Mapping, Geochemical Indices and Health Risk, Fresenius environmental bulletin, vol.28(8), 2019, p.6059-6069.

[13] Kozlu, H., Prichard, H., Melcher, F., Fisher, P., Brough, C., Stueben, D., Platinum Group Element (PGE) Mineralisation and Chromite Geochemistry in the Berit Ophiolite (Elbistan/Kahramanmaraş), SE Turkey, Ore Geology Reviews, vol.60, 2014, p.97-111. 
[14] Gandhi, M.R., Yamada, M., Haga, K., Shibayama, A., Synthesis of Pincer-type Extractants for Selective Extraction of Palladium from PGMs: An Improved Liquidliquid Extraction Approach to Current Refining Processes, Scientific Reports, vol.7(1), 2017, p.1-13.

[15] Firmansyah, M.L., Kubota, F., Goto, M., Selective Recovery of Platinum Group Metals from Spent Automotive Catalysts by Leaching and Solvent Extraction, Journal of Chemical Engineering of Japan, vol.52(11), 2019, p.835-842.

[16] Jackson-Brown, S., Scoates, J.S., Nixon, G.T., Ames, D.E., Mineralogy of Sulphide, Arsenide, and Platinum Group Minerals from the $D J / D B$ Zone of the Turnagain Alaskan-type Ultramafic Intrusion, NorthCentral British Columbia, Geological Fieldwork 2013, British Columbia Ministry of Energy and Mines, British Columbia Geological Survey Paper 2014-1, 2014.

[17] Izatt, R.M., Izatt, S.R., Bruening, R.L., Izatt, N.E., Moyer, B.A., Challenges to Achievement of Metal Sustainability in Our High-tech Society, Chemical Society Reviews, 43(8), 2014, p.2451-2475.

[18] Coggon, J. A., Nowell, G. M., Pearson, D. G., Parman, S. W., Application of the 190Pt-1860s Isotope System to Dating Platinum Mineralization and Ophiolite Formation: an Example from the Meratus Mountains, Borneo, Economic Geology, vol.106(1), 2011, p.93-117.

[19] Irzon, R., Abdullah, B., Element Mobilization During Weathering Process of Ultramafic Complex in North Konawe Regency, Southeast Sulawesi Based on A Profile from Asera, Indonesian Journal on Geoscience, vol.5(3), 2018, p.277-290.

[20] Nassar, N.T., Limitations to Elemental Substitution as Exemplified by the Platinum-group Metals, Green Chemistry, vol.17(4), 2015, p.2226-2235.

[21] Balaram, V., Singh, S.P., Satyanarayanan, M., Anjaiah, K.V., Platinum Group Elements Geochemistry of Ultramafic and Associated Rocks from Pindar in Madawara Igneous Complex, Bundelkhand Massif, Central India, Journal of earth system science, vol.122(1), 2013, p.79-91.

[22] Asai, S., Yomogida, T., Saeki, M., Ohba, H., Hanzawa, Y., Horita, T., Kitatsuji, Y., Determination of 107Pd in Pd Recovered by Laser-Induced Photoreduction with Inductively Coupled Plasma Mass
Spectrometry, Analytical

chemistry, vol.88(24), 2016 p.12227-12233.

[23] Oberthür, T., Melcher, F., Fusswinkel, T., van den Kerkhof, A.M., Sosa, G.M., The Hydrothermal Waterberg Platinum Deposit, Mookgophong (Naboomspruit), South Africa. Part 1: geochemistry and ore mineralogy, Mineralogical Magazine, vol.82(3), 2018, p.725-749.

[24] Irzon, R., Kurnia, K., Sendjaja, P., Harisaputra, D., Baharuddin, B., Pengaruh Pelapukan Terhadap Kadar Platina dan Paladium Nikel Laterit Konawe Utara, Jurnal Teknologi Mineral dan Batubara, 15(2), 2019, p.97-108.

[25] Altinkaya, P., Mäkinen, J., Kinnunen, P., Kolehmainen, E., Haapalainen, M., Lundström, M., Effect of Biological Pretreatment on Metal Extraction from Flotation Tailings for Chloride Leaching, Minerals Engineering, vol.129, 2018, p.47-53.

[26] Silitonga P.H., Peta Geologi Lembar Bandung, Jawa, Skala 1: 100.000, Pusat Penelitian dan Pengembangan Geologi, Bandung, 2013.

[27] Khaira, K., Analisis Kadar Tembaga (Cu) dan Seng (Zn) Dalam Air Minum Isi Ulang Kemasan Galon di Kecamatan Lima Kaum Kabupaten Tanah Datar, Sainstek: Jurnal Sains dan Teknologi, vol.6(2), 2016, p.116123.

[28] Warni, D., Karina, S. and Nurfadillah, N., Analisis Logam Pb, Mn, Cu dan Cd Pada Sedimen di Pelabuhan Jetty Meulaboh, Aceh Barat, Jurnal IImiah Mahasiswa Kelautan Perikanan Unsyiah, 2(2), 2017, p. 246-253.

[29] Azis, M.Y., Putri, T.R., Aprilia, F.R., Ayuliasari, Y., Hartini, O.A.D., Putra, M.R., Eksplorasi Kadar Kalsium (Ca) dalam Limbah Cangkang Kulit Telur Bebek dan Burung Puyuh Menggunakan Metode titrasi dan $A A S$, al-Kimiya: Jurnal IImu Kimia dan Terapan, vol.5(2), 2018, p.74-77.

[30] Budiyanto, F., Graphite Furnace Atomic Absortion Spectrophotometry Sebagai Metode Analisis Logam Berat, Oseana, vol.42(3), 2017, p.9-20.

[31] Butcher, D. J., Molecular Absorption Spectrometry in Flames and Furnaces: $A$ review, Analytica Chimica Acta, vol.804, 2013, p.1-15.

[32] Permatasari, N.V., Kawigraha, A., Hapid, A., Wibowo, N., Identifikasi Perubahan Mineral Selama Proses Pemanasan Pelet 
M.I.P.I. Vol.15, No 2, August 2021 - (121-129)

Komposisi Nikel dengan Analisis Difraksi Sinar $X$, Majalah IImiah Pengkajian Industri, vol.12(1), 2018, p.9-16.

[33] Chappell, D.L., Lee, A.Y., Castro-Perez, J., Zhou, H., Roddy, T.P., Lassman, M.E., Shankar, S.S., Yates, N.A., Wang, W.,
Laterza, O.F., An Ultrasensitive Method for the Quantitation of Active and Inactive GLP-1 in Human Plasma via Immunoaffinity

$L C$ 